\title{
Differential Diagnosis of Cushing's Syndrome
}

\begin{abstract}
The differential diagnosis of Cushing's syndrome requires careful multidisciplinary interaction with a number of specialities, co-ordinated through endocrine centres with good experience of this condition. It is essential that the diagnosis of Cushing's syndrome be fully established before differential diagnosis is attempted. The endocrinologist needs to be aware of the pitfalls and advantages of the tests in use. We discuss the approach to the differential diagnosis of this challenging condition. (Arq Bras Endocrinol Metab 2007;51/8:1199-1206)
\end{abstract}

Keywords: Cushing's syndrome; Cortisol; ACTH; Dexamethasone; Adrenal; Pituitary

\section{RESUMO}

Diagnóstico Diferencial da Síndrome de Cushing.

O diagnóstico diferencial da síndrome de Cushing requer uma interação multidisciplinar cuidadosa entre várias especialidades, coordenadas através de centros de endocrinologia com boa experiência nessa condição. É essencial que o diagnóstico da síndrome de Cushing seja estabelecido antes da tentativa de diagnóstico diferencial. $O$ endocrinologista precisa estar atento às possíveis falhas e vantagens dos testes empregados. Nós discutiremos a abordagem do diagnóstico diferencial nessa condição desafiadora. (Arq Bras Endocrinol Metab 2007;51/8:1199-1206)

Descritores: Síndrome de Cushing; Cortisol; ACTH; Dexametasona; Adrenal; Hipófise

$\mathrm{O}$ NCE THE DIAGNOSIS of the hypercortisolism of Cushing's syndrome is firmly established, attention can be turned to establishing the cause. This is an important point as all the tests used in the differential diagnosis depend on the prior demonstration of hypercortisolism. If there is any doubt diagnostic tests should be repeated, if needed on several occasions, before continuing on the differential diagnostic pathways. We give an overview of the differential diagnostic pathway, of which the individual parts are also discussed in detail in other articles in this edition.

\section{CAUSES OF CUSHING'S SYNDROME}

To understand the limitations of the various tests used in the differential diagnosis of Cushing's syndrome it is important to know the approximate likelihood of the cause. Endogenous Cushing's syndrome is com-

\section{revisão}

\author{
John NeWELL-Price \\ Ashley B. GROSSMAN
}

Academic Unit of Diabetes, Endocrinology \& Metabolism, School of Medicine and Biomedical Science, The University of Sheffield, Sheffield, UK (JN-P), and Dept. of Endocrinology, William Harvey Research Institute, Barts and the London, Queen Mary's School of Medicine and Dentistry, London EClA 7BE, UK (ABG). 
moner in women than men and is divided into adrenocorticotrophin (ACTH)-dependent, and ACTH-independent, causes (table 1). Overall, ACTH-dependent causes account for approximately $80-85 \%$ of cases, and of these $80 \%$ are due to pituitary adenomas (Cushing's disease), with the remaining $20 \%$ or so due to the ectopic ACTH syndrome $(1,2)$. Ectopic ACTH secretion is most commonly from small cell carcinoma of the lung and bronchial carcinoid tumours, but may also occur with almost any endocrine tumour from many different organs (e.g. phaeochromocytoma, pancreatic neuroendocrine tumours, gut carcinoids) (table 2) $(3,5)$. When the ectopic ACTH syndrome is due to small cell carcinoma of the lung it may have a rapid onset with severe features of muscle weakness, but without the classical Cushing's phenotype. In contrast, the clinical phenotype (and some biochemical features) of carcinoid tumours may be indistinguishable from that of Cushing's disease (3-6). In ectopic ACTH syndrome when the source of ACTH is apparent on simple imaging, this is referred to as the 'overt' ectopic ACTH syndrome and may be due to rapidly progressive small cell lung cancer or a more indolent source. If the source of ectopic ACTH is found only after extensive imaging this is referred to as 'covert' ectopic ACTH, whilst if the source is not found despite extensive imaging, this is termed 'occult'.

ACTH-independent Cushing's syndrome is due in most cases to a unilateral tumour: adrenal adenoma in $60 \%$ and carcinoma in $40 \%$ of cases. Very rare adrenal causes of Cushing's syndrome are ACTH-independent macronodular adrenal hyperplasia (AIMAH), primary pigmented nodular adrenal disease (PPNAD) (either as isolated disease or as part of Carney complex), and the McCune Albright syndrome $(2,7,8)$.

\section{ESTABLISHING THE AETIOLOGY OF CUSHING'S SYNDROME (figure 1)}

\section{Measurement of plasma ACTH}

The differential diagnosis of Cushing's syndrome is best done in major referral centres. Investigation will vary depending upon the availability of the biochemical tests and imaging detailed below. The first step is to measure plasma ACTH. Levels consistently below 5 $\mathrm{pg} / \mathrm{ml}$ indicate ACTH-independent Cushing's syndrome. In this case the next step is imaging the adrenal glands with CT or MRI. Levels of ACTH persistently above $15 \mathrm{pg} / \mathrm{ml}$ almost always reflect ACTHdependent pathologies and require investigation, as detailed below. Plasma ACTH values between 5-15 $\mathrm{pg} / \mathrm{ml}$ need careful interpretation since some patients with Cushing's disease and adrenal pathologies may have intermediate values $(2,9,10)$. It is essential that the sample for plasma ACTH is separated rapidly and stored at $-40^{\circ} \mathrm{C}$ to avoid degradation and a falsely low result. A positive CRH test (see below) can be useful to demonstrate ACTH-dependent hypercortisolism in an occasional patient with Cushing's disease with low baseline ACTH plasma levels.

\section{ACTH-independent Cushing's syndrome}

When adrenal adenoma, carcinoma or AIMAH is the cause of ACTH-independent Cushing's syndrome, the anatomical cause is invariably visible on imaging with CT (11). In cases of unilateral adrenal adenomas and carcinomas causing Cushing's syndrome it is usual for the contra-lateral adrenal gland to undergo atrophy in the prolonged absence of plasma ACTH. One simple means of assessing the size of the limbs of the adrenal gland is to compare them to the adjacent crus of the diaphragm on CT - if larger than the width of the

Table 1. Aetiology of Cushing's syndrome.

\begin{tabular}{|ccc|}
\hline Cause of Cushing's syndrome & F:M \\
\hline ACTH-dependent & & \\
\hline Cushing's disease & $70 \%$ & $3.5: 1$ \\
\hline Ectopic ACTH syndrome & $10 \%$ & $1: 1$ \\
\hline Unknown source of ACTH* & $5: 1$ \\
\hline ACTH-independent & $5 \%$ & $4: 1$ \\
\hline Adrenal adenoma & $10 \%$ & $1: 1$ \\
\hline Adrenal carcinoma & $5 \%$ & \\
\hline Macronodular hyperplasia (AIMAH) & $<2 \%$ & \\
\hline Primary pigmented nodular adrenal disease (PPNAD) & $<2 \%$ & \\
\hline McCune Albright syndrome & $<2 \%$ & \\
\hline * Patients may ultimately prove to have Cushing's disease. & & \\
\hline
\end{tabular}


Table 2. Aetiology of ectopic ACTH secretion.

\begin{tabular}{|c|c|c|c|}
\hline & \multicolumn{3}{|c|}{ Institution } \\
\hline & NIH & Barts & Sao Paulo \\
\hline Bronchial carcinoid tumour & 35 & 12 & 10 \\
\hline Small cell lung carcinoma & 3 & 7 & \\
\hline Pulmonary Tumourlets & & 1 & \\
\hline Thymic carcinoid tumour & 5 & 2 & 4 \\
\hline Medullary thyroid carcinoma & 2 & 3 & \\
\hline Pancreatic carcinoid tumour & 1 & 3 & 3 \\
\hline Gastrinoma & 6 & 3 & \\
\hline Appendix & 1 & & \\
\hline Other GI Neuroendocrine tumours (NET) & & 13 & \\
\hline Mesothelioma & 1 & & \\
\hline Colonic carcinoma & & 2 & \\
\hline Phaeochromocytoma & 5 & 1 & 5 \\
\hline Olfactory Ethesioneuroblastoma & & 1 & \\
\hline Disseminated carcinoid tumour & & 2 & \\
\hline Lymph Node NET & & 2 & \\
\hline Glomus tumour & & & 1 \\
\hline Unknown & 17 & 2 & 2 \\
\hline Overt & 46 & 26 & 20 \\
\hline Covert & 23 & 9 & 3 \\
\hline Occult & 17 & 5 & 2 \\
\hline Total & 90 & 40 & 25 \\
\hline
\end{tabular}

Data derived from: NIH - Ilias et al. (ref. 5); Barts - Isidori et al. (ref. 4); Sao Paulo - Salgado et al. (ref. 3).

\section{Cushing's syndrome confirmed}

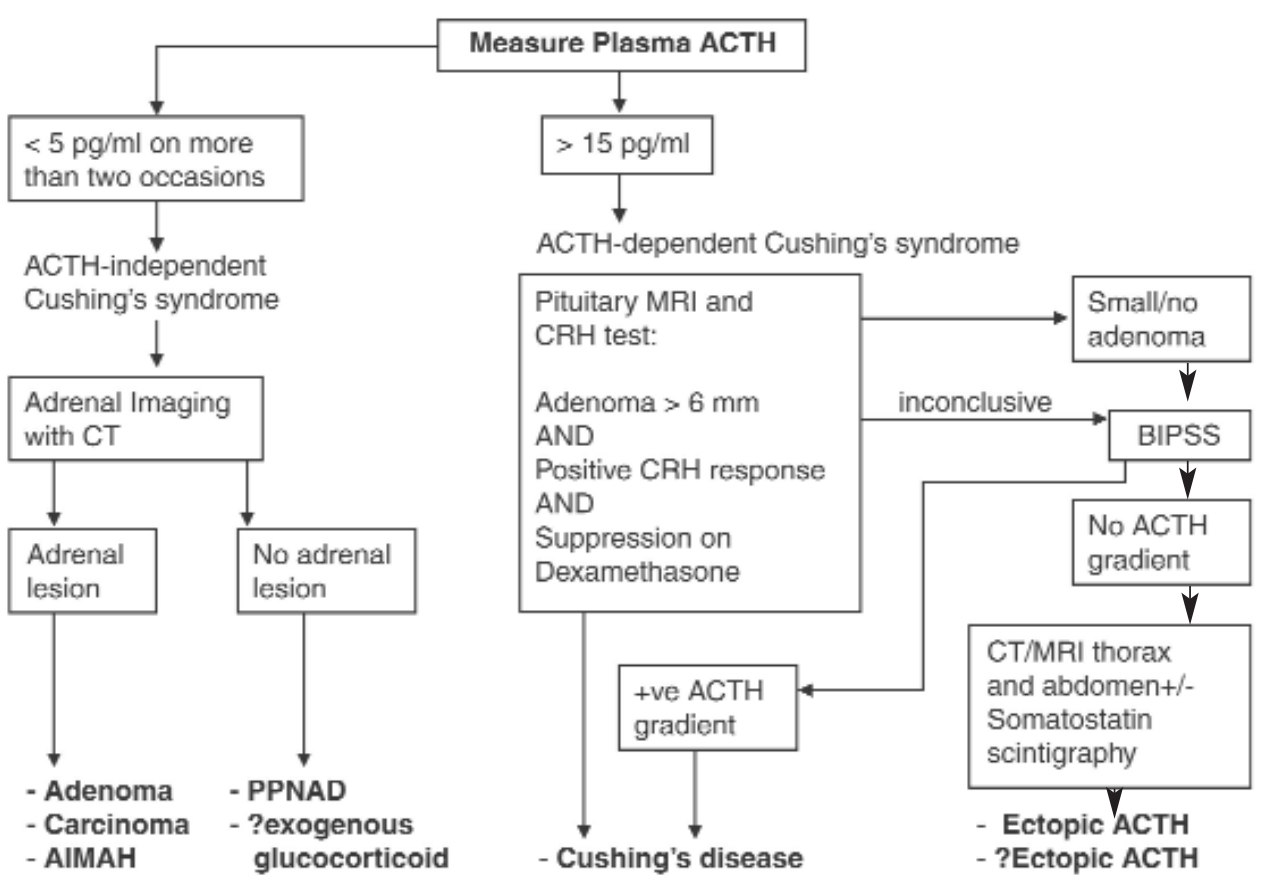

Figure 1. Diagnosis of cause of Cushing's syndrome.

AIMAH: ACTH-independent macronodular hyperplasia, PPNAD: primary pigmented nodular adrenal disease, BIPSS: bilateral inferior petrosal sinus sampling, SCLC: small cell lung cancer. 
diaphragm, as seen on CT, hyperplasia is possible and caution is needed to ensure that bilateral disease is not inadvertently characterised as unilateral.

In PPNAD, the adrenal glands may appear normal. Thus, in an established diagnosis of ACTH-independent Cushing's syndrome with normal appearances of the adrenal glands on imaging assessment of other features of Carney complex (lentigines, myxoma), and genetic testing for mutations of PRKARIA may be of benefit as a diagnostic procedure. Exogenous glucocorticoid ingestion (especially hydrocortisone but also synthetic glucocorticoids that cross react in the cortisol assay) should also be reconsidered in this setting.

\section{ACTH-dependent Cushing's syndrome}

\section{Overview}

Differentiating between pituitary and non-pituitary sites of excess ACTH secretion may be a considerable challenge in clinical endocrinology. Neuroendocrine (carcinoid) tumours may be clinically indistinguishable from Cushing's disease. Moreover, as they are usually small they are frequently difficult to identify with imaging, especially if radiological (pituitary, thoracic, pancreatic) "incidentalomas" complicate interpretation. It is for these reasons that biochemical evaluation is relied upon rather than imaging, to differentiate between pituitary and non-pituitary causes (1-5). It is important to note that in women with ACTH-dependent Cushing's syndrome 9 out of 10 cases will be due to Cushing's disease. It is against this pre-test likelihood that the performance of any test needs to be judged. If a patient has ACTH-dependent Cushing's syndrome, with responses both on dexamethasone suppression and $\mathrm{CRH}$ testing suggesting pituitary disease, and the pituitary MRI scan shows an isolated lesion of $6 \mathrm{~mm}$ or more, most will regard the diagnosis of Cushing's disease to have been made. A major problem is that up to $40 \%$ of patients with proven Cushing's disease have normal pituitary MRI scans (9). The results of $\mathrm{CRH}$ and dexamethasone tests, and pituitary MRI, should be considered together, and bilateral inferior petrosal sinus sampling (BIPSS) is usually recommended unless there is a clear diagnosis (figure 2).

\section{Plasma potassium}

High levels of cortisol may either saturate the $11 \beta$ hydroxysteroid dehydrogenase type II enzyme in the kidney, or decrease expression of this enzyme, allowing cortisol to act even more as a mineralocorticoid (12). The commonest cause of hypokalaemia is the ectopic ACTH syndrome, but it is also present in those patients with Cushing's disease with extremely high cortisol production (approximately 10\% of patients) (2).

\section{Plasma ACTH}

The circulating levels of plasma ACTH are usually lower in patients with Cushing's disease compared to those with ectopic secretion. There is, however, considerable overlap and this means that the absolute levels cannot be used reliably to discriminate between groups.

\section{DYNAMIC NON-INVASIVE TESTS}

\section{High-dose dexamethasone-suppression test (HDDST)}

The high dose dexamethasone suppression tests have been in widespread use for many years. In most centres either dexamethasone $2 \mathrm{mg}$ given every 6 hours for 48 hours, or a single $8 \mathrm{mg}$ dose is given with serum or urinary cortisol measured at the beginning and end of the test. Measurement of serum cortisol is easier and superior to measurement of urinary free cortisol or steroid metabolites. The HDDST relies upon the relative sensitivity of pituitary corticotroph adenomas to the effects of glucocorticoids, compared to the resistance exhibited by non-pituitary tumours. Approximately $80 \%$ of patients with Cushing's disease will demonstrate suppression of the serum cortisol to a value of $<50 \%$ of the basal level (2). This is less than the pre-test likelihood of Cushing's disease, and thus, by itself, the high dose dexamethasone suppression test has little diagnostic utility (13). Moreover, in very large series we have shown that when utilising the 48hour low-dose dexamethasone-suppression test, if there has already been the demonstration of suppression of serum cortisol by more than $30 \%$, there is no further advantage to going on to a high dose dexamethasone suppression test (14). Therefore, overall, we would not recommend the continued routine use of the HDDST except when BIPSS is not available.

\section{The corticotrophin-releasing hormone (CRH) test}

The basis of the corticotropin-releasing hormone test is that CRH stimulates corticotroph tumour cells in the pituitary to release ACTH and hence increase serum cortisol concentrations, whilst responses are uncommon in the ectopic ACTH syndrome. This is because of the frequent expression of the CRH-1 receptor in corticotroph tumours, which is rare in 
ectopic tumours. Recombinant human or ovinesequence $\mathrm{CRH}$ is administered as an intravenous bolus dose of either $1 \mu \mathrm{g} / \mathrm{kg}$, or in adults $100 \mu \mathrm{g} \mathrm{IV}$. The ovine-sequence CRH test has a sensitivity of 93\% for Cushing's disease based on ACTH responses at 15 and 30 minutes (15). Using more extensive sampling (up to 90 minutes) and a more stringent cut-off point of a $50 \%$ increment in plasma ACTH, ovine-sequence $\mathrm{CRH}$ had a sensitivity of $86 \%$ for Cushing's disease (16). An almost identical sensitivity is found for the human sequence peptide sampling at the same time points (17). Responses to both CRH testing and the high-dose dexamethasone suppression test are also more frequently discordant in patients with Cushing's disease secondary to a pituitary macroadenoma (18).

\section{Desmopressin testing}

Since the V3 receptor is expressed in pituitary and many ectopic tumours secreting ACTH (19-22), the desmopressin test is of limited utility in the differential diagnosis of ACTH-dependent Cushing's syndrome $(23,24)$. Similarly, a combined test using CRH and desmopressin has been used (25), but larger series have suggested that there remains overlap between responses in patients with Cushing's disease and the ectopic ACTH syndrome (26) due to the more frequent expression of the $\mathrm{V} 3$ receptor in ectopic tumours.

\section{INVASIVE TESTING}

\section{Bilateral inferior petrosal sinus sampling (BIPSS)}

Sampling of the gradient of ACTH from the pituitary to the periphery is the most reliable means for discriminating between pituitary and non-pituitary sources of ACTH. When there is a central source of ACTH there is a gradient of the value of plasma ACTH compared to the simultaneous peripheral sample, since the pituitary effluent drains via the cavernous sinuses to the petrosal sinuses and then the jugular bulb. BIPSS is a highly skilled and invasive technique, requiring placement of catheters in both inferior petrosal sinuses. Catheter position and venous anatomy require confirmation by venography, as non-uniform drainage is not uncommon. The diagnostic accuracy of the test requires the administration of CRH. A basal central: peripheral ratio of $>2: 1$ or a $\mathrm{CRH}$ stimulated ratio of $>3: 1$ is consistent with Cushing's disease (27). The combined data for many series indicates a sensitivity and a specificity of $94 \%$ (28). Small series data have suggested that these false negative responses can be identified by simultaneous sampling of prolactin to correct values in ACTH $(29,30)$. It is possible that falsely positive results may be caused by inadequate suppression of the normal corticotrophs and the duration and amount of hypercortisolism should be assessed prior to the test. Where CRH is unobtainable or too costly, desmopressin offers a reasonable alternative, but few patients with ectopic ACTH secretion have been studied in this way $(31,32)$. Using both peptides during BIPSS in combination has also been recently reported and appears effective, but again few patients with ectopic ACTH have been studied (33).

In adults, BIPSS is only $70 \%$ accurate for lateralisation of the source of ACTH within the pituitary gland $(2,10)$, but in children it may have greater accuracy for this purpose than MRI (34). Sampling from the cavernous sinuses directly does not improve accuracy (35).

\section{Internal jugular venous sampling}

Sampling from the internal jugular vein has been proposed as a simplified procedure. Direct comparison in the same patients has shown this to be inferior to BIPSS (36). One application of this test, however, may be in centres of limited sampling experience, and BIPSS (performed in a referral centre) reserved if the results are negative $(37)$.

\section{IMAGING}

\section{Adrenal}

CT gives the best resolution of adrenal anatomy. It is important to note that in ACTH-dependent Cushing's syndrome nodules may occur and adrenal hyperplasia is not always symmetrical. This can cause diagnostic confusion with a unilateral primary adrenal cause if the biochemistry is not strictly assessed. Conversely, in $30 \%$ of Cushing's disease the adrenal glands appear normal, whilst in ectopic ACTH the adrenals are virtually always homogeneously enlarged (38).

\section{Pituitary}

Up to $40 \%$ of corticotroph adenomas causing Cushing's disease in adults are not visible on standard sequence 1.5 tesla MRI scanning (9). This fact is further complicated by a $10 \%$ rate of pituitary incidentalomas in the normal population (39), emphasising the need for careful biochemical discrimination of pituitary from non-pituitary sources of ACTH. Therefore, in the absence of a pituitary macroadenoma, an abnormal MRI is not conclusive evidence in favour of Cushing's disease. 
Corticotroph tumours that are visible usually fail to enhance following gadolinium on $\mathrm{Tl}$-weighted imaging. The use of dynamic MRI, with the administration of intravenous contrast media and rapid sequence acquisition following this, does not improve the overall diagnostic rate. However, spoiled gradient sequences may have greater sensitivity in adults (40) and children (41).

\section{Imaging in the ectopic ACTH syndrome}

If clinical and biochemical assessments suggest a non-pituitary source of ACTH, then detailed further imaging studies are needed. Axial imaging with thin cut multi-slice CT of thorax and abdomen, and/or MRI of the thorax, has the highest detection rate for the ectopic ACTH syndrome. Small neuroendocrine tumours frequently express somatostatin receptors and may be disclosed on somatostatin receptor scintigraphy. However, while standard somatostatin scintigraphy may confirm functionality for a lesion found on axial imaging, it has only rarely been shown to disclose truly "occult" tumours that are not visible on CT $(2,4,5,42-44)$. Using higher than standard doses of radionuclide may, in some cases, disclose lesions that were otherwise negative on imaging. In patients with recurrent disease, somatostatin scintigraphy may be useful for follow-up (45) as it has a low false-positive rate (46). Positron emission tomography (PET) with 18 -flurodeoxyglucose (FDG) is of little benefit as such tumours are usually of low metabolic activity (47). The use of ${ }^{11} \mathrm{C}-5$ hydroxytryptophan with PET has been proposed as a universal imaging technique for neuroendocrine tumours, but few patients have been studied (48) and further experience is required to determine its utility. There is also increasing interest in ${ }^{68} \mathrm{Ga}$ octreotate PET scanning. Despite extensive investigation, the cause of ACTH may remain 'occult' in $5-15 \%$ of patients, and these require continued follow-up. Over time the number remaining undiagnosed reduces as tests are repeated, although establishing the cause occasionally may take up to 20 years of follow up (49).

\section{CONCLUSIONS}

The differential diagnosis of Cushing's syndrome requires multidisciplinary interaction with a number of specialities, co-ordinated through endocrine centres with good experience of this condition. It is essential the diagnosis of Cushing's syndrome be fully estab- lished before differential diagnosis is attempted. The endocrinologist needs to be aware of the pitfalls of the tests in use, and that these may need repeating over time if the source of ACTH is not found at initial diagnostic workup.

\section{REFERENCES}

1. Newell-Price J, Bertagna X, Grossman AB, Nieman LK. Cushing's syndrome. Lancet 2006;367:1605-17.

2. Newell-Price J, Trainer P, Besser M, Grossman A. The diagnosis and differential diagnosis of Cushing's syndrome and pseudo-Cushing's states. Endocr Rev 1998;19:647-72.

3. Salgado LR, Fragoso MC, Knoepfelmacher M, Machado MC, Domenice S, Pereira MA, et al. Ectopic ACTH syndrome: our experience with 25 cases. Eur J Endocrinol 2006; $155: 725-33$.

4. Isidori AM, Kaltsas GA, Pozza C, Frajese V, Newell-Price J, Reznek $\mathrm{RH}$, et al. The ectopic adrenocorticotropin syndrome: clinical features, diagnosis, management, and long-term follow-up. J Clin Endocrinol Metab 2006;91:371-7.

5. Ilias I, Torpy DJ, Pacak K, Mullen N, Wesley RA, Nieman LK. Cushing's syndrome due to ectopic corticotropin secretion: twenty years' experience at the National Institutes of Health. J Clin Endocrinol Metab 2005;90:4955-62.

6. Aniszewski JP, Young WF, Jr., Thompson GB, Grant CS, van Heerden JA. Cushing syndrome due to ectopic adrenocorticotropic hormone secretion. World J Surg 2001;25:934-40.

7. Nieman LK. Cushing's syndrome. Philadephia: W.B. Saunders Company, 2001.

8. Lacroix A, Ndiaye N, Tremblay J, Hamet P. Ectopic and abnormal hormone receptors in adrenal Cushing's syndrome. Endocr Rev 2001;22:75-110.

9. Invitti C, Pecori Giraldi F, de Martin M, Cavagnini F. Diagnosis and management of Cushing's syndrome: results of an Italian multicentre study. Study Group of the Italian Society of Endocrinology on the Pathophysiology of the Hypothalamic-Pituitary-Adrenal Axis. J Clin Endocrinol Metab 1999;84:440-8.

10. Arnaldi G, Angeli A, Atkinson AB, Bertagna X, Cavagnini F, Chrousos GP, et al. Diagnosis and complications of Cushing's syndrome: a consensus statement. J Clin Endocrinol Metab 2003;88:5593-602.

11. Rockall AG, Babar SA, Sohaib SA, Isidori AM, Diaz-Cano S, Monson JP, et al. CT and MR imaging of the adrenal glands in ACTH-independent Cushing syndrome. Radiographics 2004;24:435-52.

12. Stewart PM, Walker BR, Holder G, O'Halloran D, Shackleton $\mathrm{CH} .11$ beta-Hydroxysteroid dehydrogenase activity in Cushing's syndrome: explaining the mineralocorticoid excess state of the ectopic adrenocorticotropin syndrome. J Clin Endocrinol Metab 1995;80(12):3617-20.

13. Aron DC, Raff H, Findling JW. Effectiveness versus efficacy: the limited value in clinical practice of high dose dexamethasone suppression testing in the differential diagnosis of adrenocorticotropin-dependent Cushing's syndrome. J Clin Endocrinol Metab 1997;82(6):1780-5.

14. Isidori AM, Kaltsas GA, Mohammed S, Morris DG, Jenkins P, Chew $\mathrm{SL}$, et al. Discriminatory value of the low-dose dexamethasone suppression test in establishing the diagnosis and differential diagnosis of Cushing's syndrome. J Clin Endocrinol Metab 2003;88(11):5299-306.

15. Nieman LK, Oldfield EH, Wesley R, Chrousos GP, Loriaux $\mathrm{DL}$, Cutler GB, Jr. A simplified morning ovine corticotropin-releasing hormone stimulation test for the differential diagnosis of adrenocorticotropin-dependent Cushing's syndrome. J Clin Endocrinol Metab 1993;77(5):1308-12. 
16. Reimondo G, Paccotti P, Minetto M, Termine A, Stura G, Bergui $\mathrm{M}$, et al. The corticotrophin-releasing hormone test is the most reliable noninvasive method to differentiate pituitary from ectopic ACTH secretion in Cushing's syndrome. Clin Endocrinol (Oxf) 2003;58(6):718-24.

17. Newell-Price J, Morris DG, Drake WM, Korbonits M, Monson JP, Besser GM, et al. Optimal response criteria for the human $\mathrm{CRH}$ test in the differential diagnosis of ACTH-dependent Cushing's syndrome. J Clin Endocrinol Metab 2002; 87(4):1640-5.

18. Woo YS, Isidori AM, Wat WZ, Kaltsas GA, Afshar F, Sabin I, et al. Clinical and biochemical characteristics of adrenocorticotropin-secreting macroadenomas. J Clin Endocrinol Metab 2005;90(8):4963-9.

19. Arlt W, Dahia PL, Callies F, Nordmeyer JP, Allolio B, Grossman $A B$, et al. Ectopic ACTH production by a bronchial carcinoid tumour responsive to desmopressin in vivo and in vitro. Clin Endocrinol (Oxf) 1997;47(5):623-7.

20. de Keyzer Y, Rene P, Lenne F, Auzan C, Clauser E, Bertagna $X$. V3 vasopressin receptor and corticotropic phenotype in pituitary and nonpituitary tumors. Horm Res 1997;47(4-6): 259-62.

21. Dahia PL, Ahmed-Shuaib A, Jacobs RA, Chew SL, Honegger $\mathrm{J}$, Fahlbusch $\mathrm{R}$, et al. Vasopressin receptor expression and mutation analysis in corticotropin-secreting tumors. J Clin Endocrinol Metab 1996;81(5):1768-71.

22. Dahia PL, Grossman AB. The molecular pathogenesis of corticotroph tumors. Endocr Rev 1999;20(2):136-55

23. Newell-Price J. The desmopressin test and Cushing's syndrome: current state of play. Clin Endocrinol (Oxf) 1997:47(2):173-4.

24. Tsagarakis S, Tsigos C, Vasiliou V, Tsiotra P, Kaskarelis J, Sotiropoulou C, et al. The desmopressin and combined CRHdesmopressin tests in the differential diagnosis of ACTHdependent Cushing's syndrome: constraints imposed by the expression of $\mathrm{V} 2$ vasopressin receptors in tumors with ectopic ACTH secretion. J Clin Endocrinol Metab 2002; 87(4):1646-53.

25. Newell-Price J, Perry L, Medbak S, Monson J, Savage M, Besser $\mathrm{M}$, et al. A combined test using desmopressin and corticotropin-releasing hormone in the differential diagnosis of Cushing's syndrome. J Clin Endocrinol Metab 1997; 82(1):176-81.

26. Tsagarakis $\mathrm{S}$, Kaskarelis IS, Kokkoris $\mathrm{P}$, Malagari $\mathrm{C}$, Thalassinos $\mathrm{N}$. The application of a combined stimulation with $\mathrm{CRH}$ and desmopressin during bilateral inferior petrosal sinus sampling in patients with Cushing's syndrome. Clin Endocrinol (Oxf) 2000;52(3):355-61.

27. Oldfield EH, Doppman JL, Nieman LK, Chrousos GP, Miller $\mathrm{DL}$, Katz DA, et al. Petrosal sinus sampling with and without corticotropin-releasing hormone for the differential diagnosis of Cushing's syndrome. N Engl J Med 1991; 325(13): 897-905.

28. Lindsay JR, Nieman LK. Differential diagnosis and imaging in Cushing's syndrome. Endocrinol Metab Clin North Am 2005;34(2):403-21.

29. McNally PG, Bolia A, Absalom SR, Falconer-Smith J, Howlett TA. Preliminary observations using endocrine markers of pituitary venous dilution during bilateral simultaneous inferior petrosal sinus catheterization in Cushing's syndrome: is combined CRF and TRH stimulation of value? Clin Endocrinol (Oxf) 1993;39(6):681-6.

30. Findling JW, Kehoe ME, Raff H. Identification of patients with Cushing's disease with negative pituitary adrenocorticotropin gradients during inferior petrosal sinus sampling: prolactin as an index of pituitary venous effluent. J Clin Endocrinol Metab 2004;89(12):6005-9.

31. Machado MC, de Sa SV, Domenice S, Fragoso MC, Puglia P $\mathrm{Jr}$, Pereira MA, et al. The role of desmopressin in bilateral and simultaneous inferior petrosal sinus sampling for differential diagnosis of ACTH-dependent Cushing's syndrome. Clin Endocrinol (Oxf) 2007;66(1):136-42.
32. Gannage-Yared MH, Slaba S, Rizk T, Chidiac Wehbe RM. Use of desmopressin as an alternative to corticotropinreleasing hormone during inferior petrosal sinus sampling in a child with Cushing's disease. J Endocrinol Invest 2007; 30(5):434-8.

33. Tsagarakis S, Vassiliadi D, Kaskarelis IS, Komninos J, Souvatzoglou $E$, Thalassinos N. The application of the combined corticotropin-releasing hormone plus desmopressin stimulation during petrosal sinus sampling is both sensitive and specific in differentiating patients with Cushing's disease from patients with the occult ectopic adrenocorticotropin syndrome. J Clin Endocrinol Metab 2007;92(6):2080-6.

34. Lienhardt A, Grossman AB, Dacie JE, Evanson J, Huebner A, Afshar F, et al. Relative contributions of inferior petrosal sinus sampling and pituitary imaging in the investigation of children and adolescents with ACTH-dependent Cushing's syndrome. J Clin Endocrinol Metab 2001; 86(12):5711-4

35. Liu C, Lo JC, Dowd CF, Wilson CB, Kunwar S, Aron DC, et al. Cavernous and inferior petrosal sinus sampling in the evaluation of ACTH-dependent Cushing's syndrome. Clin Endocrinol (Oxf) 2004;61(4):478-86.

36. Erickson D, Huston J 3rd, Young WF Jr, Carpenter PC, Wermers RA, Bonelli FS, et al. Internal jugular vein sampling in adrenocorticotropic hormone-dependent Cushing's syndrome: a comparison with inferior petrosal sinus sampling. Clin Endocrinol (Oxf) 2004;60(4):413-9.

37. Ilias I, Chang R, Pacak K, Oldfield EH, Wesley R, Doppman J, et al. Jugular venous sampling: an alternative to petrosal sinus sampling for the diagnostic evaluation of adrenocorticotropic hormone-dependent Cushing's syndrome. J Clin Endocrinol Metab 2004;89(8):3795-800.

38. Sohaib SA, Hanson JA, Newell-Price JD, Trainer PJ, Monson $J P$, Grossman AB, et al. CT appearance of the adrenal glands in adrenocorticotrophic hormone-dependent Cushing's syndrome. AJR Am J Roentgenol 1999;172(4):997-1002.

39. Hall WA, Luciano MG, Doppman JL, Patronas NJ, Oldfield $\mathrm{EH}$. Pituitary magnetic resonance imaging in normal human volunteers: occult adenomas in the general population. Ann Intern Med 1994;120(10):817-20.

40. Patronas N, Bulakbasi N, Stratakis CA, Lafferty A, Oldfield $\mathrm{EH}$, Doppman J, et al. Spoiled gradient recalled acquisition in the steady state technique is superior to conventional postcontrast spin echo technique for magnetic resonance imaging detection of adrenocorticotropin-secreting pituitary tumors. J Clin Endocrinol Metab 2003; 88(4):1565-9.

41. Batista D, Courkoutsakis NA, Oldfield EH, Griffin KJ, Keil M, Patronas NJ, et al. Detection of adrenocorticotropin-secreting pituitary adenomas by magnetic resonance imaging in children and adolescents with Cushing disease. J Clin Endocrinol Metab 2005;90(9):5134-40.

42. Lamberts SW, de Herder WW, Krenning EP, Reubi JC. A role of (labeled) somatostatin analogs in the differential diagnosis and treatment of Cushing's syndrome. J Clin Endocrinol Metab 1994;78(1):17-9.

43. Wajchenberg BL, Mendonça BB, Liberman B, Pereira MA, Carneiro PC, Wakamatsu A, et al. Ectopic adrenocorticotropic hormone syndrome. Endocr Rev 1994;15(6):752-87.

44. Phlipponneau M, Nocaudie M, Epelbaum J, De Keyzer Y, Lalau JD, Marchandise $X$, et al. Somatostatin analogs for the localization and preoperative treatment of an adrenocorticotropin-secreting bronchial carcinoid tumor. J Clin Endocrinol Metab 1994;78(1):20-4.

45. Granberg D, Sundin A, Janson ET, Oberg K, Skogseid B, Westlin JE. Octreoscan in patients with bronchial carcinoid tumours. Clin Endocrinol (Oxf) 2003;59(6):793-9.

46. Tsagarakis S, Christoforaki M, Giannopoulou H, Rondogianni F, Housianakou I, Malagari C, et al. A reappraisal of the utility of somatostatin receptor scintigraphy in patients with ectopic adrenocorticotropin Cushing's syndrome. J Clin Endocrinol Metab 2003;88(10):4754-8. 
47. Pacak K, Ilias I, Chen CC, Carrasquillo JA, Whatley M, Nieman LK. The role of [(18)F]fluorodeoxyglucose positron emission tomography and [(111)In]-diethylenetriaminepentaacetate-DPhe-pentetreotide scintigraphy in the localization of ectopic adrenocorticotropin-secreting tumors causing Cushing's syndrome. J Clin Endocrinol Metab 2004;89(5):2214-21.

48. Orlefors H, Sundin A, Garske U, Juhlin C, Oberg K, Skogseid B, et al. Whole-body (11)C-5-hydroxytryptophan positron emission tomography as a universal imaging technique for neuroendocrine tumors: comparison with somatostatin receptor scintigraphy and computed tomography. J Clin Endocrinol Metab 2005:90(6):3392-400.

49. Grossman AB, Kelly P, Rockall A, Bhattacharya S, McNicol A, Barwick T. Cushing's syndrome caused by an occult source: difficulties in diagnosis and management. Nat Clin Pract Endocrinol Metab 2006;2(11):642-7.
Address for correspondence:

John Newell-Price

Senior Lecturer and Consultant Endocrinologist Academic Unit of Diabetes, Endocrinology \& Metabolism

The University of Sheffield

Room OU142

O Floor

Royal Hallamshire Hospital

Glossop Road

Sheffield, S10 2JF, UK 